\title{
Doxycycline Degradation by the Oxidative Fenton Process
}

\author{
Alexandre A. Borghi, ${ }^{1}$ Milena F. Silva, ${ }^{2}$ Saleh Al Arni, ${ }^{3}$ \\ Attilio Converti, ${ }^{4}$ and Mauri S. A. Palma ${ }^{1}$ \\ ${ }^{1}$ Department of Biochemical and Pharmaceutical Technology, Faculty of Pharmaceutical Sciences, University of São Paulo, \\ Bloco 16, Avenida Prof. Lineu Prestes 580, 05508-000 São Paulo, SP, Brazil \\ ${ }^{2}$ Biological Science Center, Federal University of Pernambuco, Avenue Prof. Moraes Rego 1235, Cidade Universitária, \\ 50670-901 Recife, PE, Brazil \\ ${ }^{3}$ Department of Chemical Engineering, King Saud University, P.O. Box 800, Riyadh 11421, Saudi Arabia \\ ${ }^{4}$ Department of Civil, Chemical and Environmental Engineering, Pole of Chemical Engineering, Genoa University, \\ Via Opera Pia 15, 16145 Genoa, Italy
}

Correspondence should be addressed to Mauri S. A. Palma; msapalma@usp.br

Received 29 November 2014; Accepted 4 February 2015

Academic Editor: Ana Moldes

Copyright (C) 2015 Alexandre A. Borghi et al. This is an open access article distributed under the Creative Commons Attribution License, which permits unrestricted use, distribution, and reproduction in any medium, provided the original work is properly cited.

Doxycycline is a broad-spectrum tetracycline occurring in domestic, industrial, and rural effluents, whose main drawback is the increasing emergence of resistant bacteria. This antibiotic could be degraded by the so-called Fenton process, consisting in the oxidation of organic pollutants by oxygen peroxide $\left(\mathrm{H}_{2} \mathrm{O}_{2}\right)$ in the presence of $\mathrm{Fe}^{2+}$. Experiments were performed according to an experimental Rotational Central Composite Design to investigate the influence of temperature $\left(0-40.0^{\circ} \mathrm{C}\right), \mathrm{H}_{2} \mathrm{O}_{2}$ concentration $(100-900 \mathrm{mg} / \mathrm{L})$, and $\mathrm{Fe}^{2+}$ concentration $(5-120 \mathrm{mg} / \mathrm{L})$ on residual doxycycline and total organic carbon concentrations. Whereas the final residual doxycycline concentration ranged from 0 to $55.8 \mathrm{mg} / \mathrm{L}$, the oxidation process proved unable to reduce the total organic carbon by more than $30 \%$. The best operating conditions were concentrations of $\mathrm{H}_{2} \mathrm{O}_{2}$ and $\mathrm{Fe}^{2+}$ of 611 and $25 \mathrm{mg} / \mathrm{L}$, respectively, and temperature of $35.0^{\circ} \mathrm{C}$, but the analysis of variance revealed that only the first variable exerted a statistically significant effect on the residual doxycycline concentration. These results suggest possible application of this process in the treatment of doxycycline-containing effluents and may be used as starting basis to treat tetracycline-contaminated effluents.

\section{Introduction}

The major source of environmental contamination by drugs is municipal wastewater, either treated or not. However, additional important contributions are given by the effluents of chemical and pharmaceutical industries, the improper disposal of expired drugs, the rural effluents, and the presence of antibiotics in animal manure used to fertilize the soil [1]. World consumption of antibiotics has increased dramatically in the last decade, thus contributing to their release into the environment, either as being in their original form or as metabolites. Most ingested antibiotics are not fully metabolized by humans and animals; therefore, about 25 to $75 \%$ of them leave the organism in unaltered form [24]. Bacterial resistance is actually now as a major concern, as there are strains resistant to almost all currently known antibiotics [5].

Tetracyclines are the third most consumed family of antibiotics, but, owing to their widespread use, a growing number of bacteria resistant to them have been detected [68]. They are considered safe antibiotics with a lot of favorable properties such as broad spectrum of antibacterial activity, low toxicity, and low cost [9]. However, there are side health effects, among which the most common are nausea, vomiting, and diarrhea; in addition, patients who take insulin must have special monitoring, since tetracyclines may increase its persistence in the body [10]. Besides their use in humans, tetracyclines are used in animal therapy to treat infections and promote growth [9]. 
Doxycycline is a tetracycline with broad spectrum of action, which is used, in both human and veterinary medicine, against a wide range of Gram-positive and Gramnegative bacteria. Because of its widespread use, its concentration can reach $6.7 \mu \mathrm{g} / \mathrm{L}$ in wastewaters and $1.5 \mathrm{mg} / \mathrm{kg}$ in domestic sewage sludge [1]; therefore, it becomes of paramount importance to set up efficient and inexpensive techniques to treat these effluents, given the increase in bacterial resistance to this antibiotic.

Several processes have been proposed for the treatment of doxycycline-containing effluents, among which there are charcoal adsorption, $\mathrm{UV}$ photolysis, ozonation [4], $\mathrm{UV} / \mathrm{H}_{2} \mathrm{O}_{2}$ photolysis [11], oxidation with $\mathrm{H}_{2} \mathrm{O}_{2}$ in the presence of $\mathrm{Cu}^{2+}$ as a catalyst [12], photocatalysis [13], $\gamma$-radiolysis, and electron pulse radiolysis of water [9]. A possible alternative to these expensive processes could be the so-called Fenton process that basically consists of the generation of hydroxyl radicals, via dissociation of hydrogen peroxide in aqueous solution catalyzed by the oxidation of the ferrous ion to the ferric one. Indeed, hydroxyl radicals are extremely reactive and nonselective and are widely used to pretreat wastewaters. The main advantages of the Fenton process are its low cost and the formation of nontoxic substances $\left(\mathrm{H}_{2} \mathrm{O}\right.$ and $\left.\mathrm{O}_{2}\right)$ by $\mathrm{H}_{2} \mathrm{O}_{2}$-induced decomposition, whereas the main drawback is the production of ferric hydroxide sludge.

The present work aims to study doxycycline degradation by the Fenton process and to optimize the experimental conditions of temperature, initial concentration of hydrogen peroxide, and initial concentration of ferrous ion in order to minimize the residual concentrations of doxycycline and total organic carbon at the end of the process.

\section{Materials and Methods}

2.1. Chemicals. Sulfuric acid (98\%), hydrogen peroxide (29\%), sodium hydroxide, and ferrous sulfate heptahydrate, potassium iodide, anhydrous sodium sulfite, sodium molybdate, sodium nitrate, methanol, acetic acid, and sodium acetate were purchased from Synth (Diadema, São Paulo, Brazil) and doxycycline hydrochloride was purchased from Calbiochem (San Diego, CA, USA). All the chemical compounds, except the solutions, were of high purity grade reagents.

2.2. Experimental Set-Up. A schematic diagram of the experimental set-up used for doxycycline degradation tests is illustrated in Figure 1.

A beaker (A) containing an aqueous solution of $100 \mathrm{mg} / \mathrm{L}$ doxycycline hydrochloride was immersed in a thermostatic bath (B), model TE 184 (Tecnal, São Paulo, SP, Brazil), for temperature regulation between 0 and $100^{\circ} \mathrm{C}$. It was equipped with a mechanical stirrer (C), model RZR 2021 (Heidolph, Schwabach, Germany), a thermocouple (D), model Gulterm 200 (Gulton, São Paulo, SP, Brazil), and a pH meter (E), model $10 \mathrm{MB}$ (Marte, São Paulo, SP, Brazil). Dosages and samplings were done using 0-20, 20-200, and 100-1000 $\mu \mathrm{L}$ micropipettes (Finnpipette, Vantaa, Finland) and an analytical balance, model AL 500 (Marte).

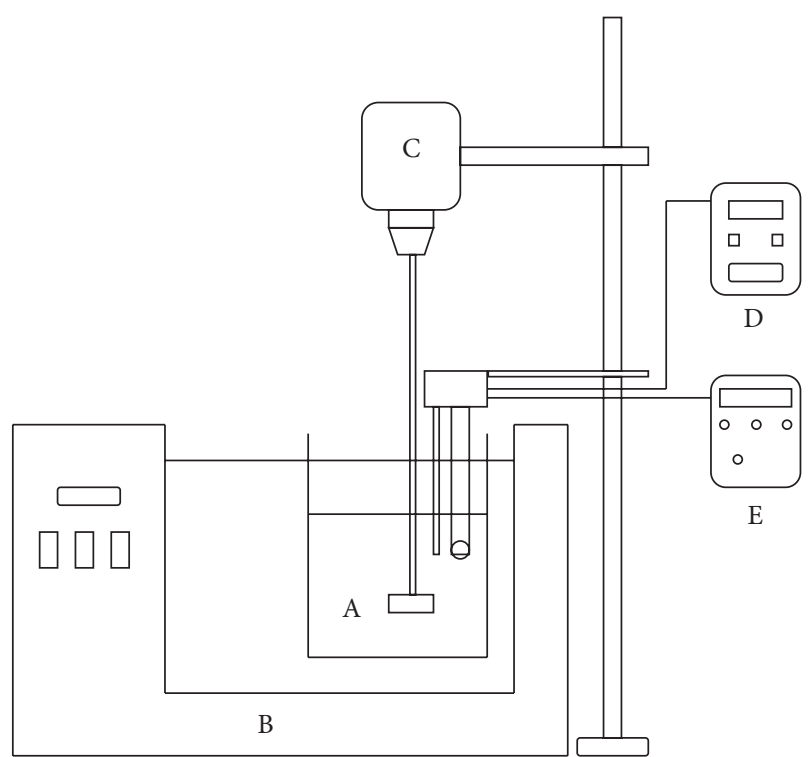

FIGURE 1: Schematic diagram of the experimental set-up used for doxycycline oxidation tests by the Fenton process. $\mathrm{A}=$ beaker containing $100 \mathrm{mg} / \mathrm{L}$ doxycycline hydrochloride solution; $\mathrm{B}=$ thermostatic bath $\left(0-100^{\circ} \mathrm{C}\right) ; \mathrm{C}=$ mechanical stirrer; $\mathrm{D}=$ thermocouple; $\mathrm{E}=\mathrm{pH}$ meter.

2.3. Experimental Design. Doxycycline oxidation tests were performed according to a Rotational Central Composite Design (RCCD) $[14,15]$, whose results in terms of residual doxycycline $\left(C_{\text {Dox }, R}\right)$ and total organic carbon (TOC) concentrations at the end of the process are listed in Table 1.

2.4. Experimental Procedure. Two hundred $\mathrm{mL}$ of $100 \mathrm{mg} / \mathrm{L}$ doxycycline hydrochloride solution was transferred to a beaker wrapped in aluminum foil in order to protect it from ambient light, which was then put in a bath thermostated at the selected temperature $\left(0,8.0,20.0,32.0\right.$, or $\left.40.0^{\circ} \mathrm{C}\right)$ and mechanically stirred at $250 \mathrm{rpm}$. Once the desired temperature had been reached, ferrous sulfate and hydrogen peroxide solutions were added to the medium up to the achievement of the desired concentrations of $\mathrm{Fe}^{2+}(5.0,28.3,62.5,96.7$, and $120 \mathrm{mg} / \mathrm{L})$ and $\mathrm{H}_{2} \mathrm{O}_{2}(100,262,500,738$, and $900 \mathrm{mg} / \mathrm{L})$. Every test started with $\mathrm{H}_{2} \mathrm{O}_{2}$ addition, whereupon a timer was activated and aliquots of the medium were collected at selected times for analyses.

\subsection{Chemical Analyses}

2.5.1. Determination of Doxycycline Concentration. Since $\mathrm{Fe}^{2+}$ and $\mathrm{H}_{2} \mathrm{O}_{2}$ are well known to interfere with the spectrophotometric determination of doxycycline, it was necessary to treat the samples with an aqueous inhibiting solution consisting of $1.0 \mathrm{M}$ potassium iodide, $1.0 \mathrm{M}$ sodium sulfite, and $0.1 \mathrm{M}$ sodium hydroxide as described by Mota et al. [16]. For this purpose, after addition of $1.0 \mathrm{~mL}$ of sample to a test tube containing $1.0 \mathrm{~mL}$ of this inhibiting solution, the resulting solution was mixed and filtered through cellulose acetate filters with $0.45 \mu \mathrm{m}$ pore diameter, model N-11106-25 
TABLE 1: Experimental conditions of tests of doxycycline degradation carried out according to the experimental RCCD, coded and uncoded values of the independent variables, and results of residual doxycycline $\left(C_{\mathrm{Dox}, R}\right)$ and total organic carbon (TOC) concentrations at the end of the Fenton process.

\begin{tabular}{|c|c|c|c|c|c|c|c|c|}
\hline Test & $X_{1}$ & $X_{2}$ & $X_{3}$ & $C_{\mathrm{Fe}^{2+}}(\mathrm{mg} / \mathrm{L})$ & $C_{\mathrm{H}_{2} \mathrm{O}_{2}}(\mathrm{mg} / \mathrm{L})$ & $T\left({ }^{\circ} \mathrm{C}\right)$ & $C_{\text {Dox }, R}(\mathrm{mg} / \mathrm{L})$ & TOC $(\mathrm{mg} / \mathrm{L})$ \\
\hline 1 & -1 & -1 & -1 & 28.3 & 262 & 8.1 & 28.6 & 38.4 \\
\hline 2 & +1 & -1 & -1 & 96.7 & 262 & 8.1 & 5.8 & 45.8 \\
\hline 3 & -1 & +1 & -1 & 28.3 & 738 & 8.1 & 18.5 & 45.0 \\
\hline 4 & +1 & +1 & -1 & 96.7 & 738 & 8.1 & 4.3 & 41.7 \\
\hline 5 & -1 & -1 & +1 & 28.3 & 262 & 31.9 & 13.6 & 41.9 \\
\hline 6 & +1 & -1 & +1 & 96.7 & 262 & 31.9 & 2.6 & 40.7 \\
\hline 7 & -1 & +1 & +1 & 28.3 & 738 & 31.9 & 7.8 & 36.0 \\
\hline 8 & +1 & +1 & +1 & 96.7 & 738 & 31.9 & 3.0 & 40.6 \\
\hline 9 & -1.68 & 0 & 0 & 5.0 & 500 & 20.0 & 4.4 & 47.4 \\
\hline 10 & +1.68 & 0 & 0 & 120.0 & 500 & 20.0 & 3.3 & 45.3 \\
\hline 11 & 0 & -1.68 & 0 & 62.5 & 100 & 20.0 & 55.8 & 46.6 \\
\hline 12 & 0 & +1.68 & 0 & 62.5 & 900 & 20.0 & 4.7 & 38.8 \\
\hline 13 & 0 & 0 & -1.68 & 62.5 & 500 & 0.0 & 21.4 & 40.7 \\
\hline 14 & 0 & 0 & +1.68 & 62.5 & 500 & 40.0 & 2.6 & 40.4 \\
\hline 15 & 0 & 0 & 0 & 62.5 & 500 & 20.0 & 0.0 & 40.4 \\
\hline 16 & 0 & 0 & 0 & 62.5 & 500 & 20.0 & 0.2 & 45.6 \\
\hline 17 & 0 & 0 & 0 & 62.5 & 500 & 20.0 & 2.0 & 45.2 \\
\hline 18 & 0 & 0 & 0 & 62.5 & 500 & 20.0 & 0.0 & 41.2 \\
\hline 19 & 0 & 0 & 0 & 62.5 & 500 & 20.0 & 0.0 & 39.2 \\
\hline 20 & 0 & 0 & 0 & 62.5 & 500 & 20.0 & 0.4 & 38.5 \\
\hline \multicolumn{7}{|c|}{ Mean results at the central point } & 0.43 & 41.7 \\
\hline & \multicolumn{6}{|c|}{ Standard deviation at the central point } & 0.52 & 3.0 \\
\hline & \multicolumn{6}{|c|}{ Variation coefficient at the central point } & 1.21 & 0.073 \\
\hline
\end{tabular}

$\mathrm{CFe}^{2+}=$ initial concentration of ferrous ion; $\mathrm{C}_{\mathrm{H}_{2} \mathrm{O}_{2}}=$ initial concentration of hydrogen peroxide; $T=$ temperature; $X_{1}=$ coded values of $C_{\mathrm{Fe}^{2+}} ; X_{2}=$ coded values of $\mathrm{C}_{\mathrm{H}_{2} \mathrm{O}_{2}} ; X_{3}=$ coded values of $T$.

(Sartorius, Göttingen, Germany). A $1.0 \mathrm{~mL}$ aliquot of the filtrate was then transferred into a $5.0 \mathrm{~mL}$ volumetric flask containing $1.0 \mathrm{~mL}$ of $0.005 \mathrm{M} \mathrm{Na}_{2} \mathrm{MoO}_{4}, 0.5 \mathrm{~mL}$ of $1.0 \mathrm{M}$ $\mathrm{NaNO}_{3}$, and $0.5 \mathrm{~mL}$ of $0.01 \mathrm{M}$ acetate buffer, the $\mathrm{pH}$ was adjusted to 5.0, and distilled water was added up to a final volume of $5.0 \mathrm{~mL}$. After mixing, the absorbance of this solution was read at a wavelength of $390 \mathrm{~nm}$ using a UVVis spectrophotometer, model $600 \mathrm{~S}$ (Femto, São Paulo, SP, Brazil). To determine the residual concentration of doxycycline in samples after treatment with the Fenton process, we used doxycycline hydrochloride solutions with known concentrations as standards.

2.5.2. Determination of Total Organic Carbon. To prepare samples for TOC concentration determination, $3.5 \mathrm{~mL}$ of the above inhibiting solution was added to $3.5 \mathrm{~mL}$ of sample, and the resulting mixture was filtered through cellulose acetate filters. $\mathrm{H}_{2} \mathrm{SO}_{4}$ 1:5 was then added to the filtrate up to a $\mathrm{pH}$ value in the range between 2.0 and 3.0, and TOC concentration was finally determined by a TOC-5000A equipment (Shimadzu, Tokyo, Japan).

2.5.3. Identification of Doxycycline Degradation Products. Samples of the reaction medium from the Fenton process carried out under the best conditions identified through the
$\operatorname{RCCD}\left(C_{\mathrm{Fe}^{2+}}=25 \mathrm{mg} / \mathrm{L}, C_{\mathrm{H}_{2} \mathrm{O}_{2}}=611 \mathrm{mg} / \mathrm{L}\right.$, and $\left.T=35.0^{\circ} \mathrm{C}\right)$ were collected after 10,30,60,90,120, and $300 \mathrm{~min}$ and submitted to LCMS-IT-TOF analysis to identify doxycycline degradation products. Thirty $\mu \mathrm{L}$ of $0.1 \mathrm{M} \mathrm{NaOH}$ was added to $2.0 \mathrm{~mL}$ aliquots of the reaction medium to precipitate $\mathrm{Fe}^{3+}$ and neutralize residual $\mathrm{H}_{2} \mathrm{O}_{2}$. The resulting solution was then filtered through cellulose acetate filters with $0.45 \mu \mathrm{m}$ pore diameter, and the $\mathrm{pH}$ adjusted to 1.5 with $\mathrm{H}_{2} \mathrm{SO}_{4} 1: 5$.

Analyses were made at $40^{\circ} \mathrm{C}$ under isocratic conditions by a liquid chromatograph, model Prominence UFLC (Shimadzu, Tokyo, Japan), coupled with a mass spectrometer LCMS-IT-TOF, and equipped with a column, model Shimpack XR-ODS $(2.0 \times 50 \mathrm{~mm}, 2 \mu \mathrm{m})$. The mobile phase was a mixture of $50 \%$ methanol and $50 \%$ acetic acid $(0.1 \%$ $\mathrm{v} / \mathrm{v})$ aqueous solutions. The mobile phase flow rate was $0.2 \mathrm{~mL} / \mathrm{min}$, the injected sample volume $1.0 \mu \mathrm{L}$, and the run time $5 \mathrm{~min}$. In the chromatograms, only peaks with height at least three times higher than the noise level were ascribed to degradation products.

\section{Results and Discussion}

Table 1 lists the results of doxycycline oxidation tests performed according to a Rotational Central Composite Design (RCCD) in which the concentration of ferrous ion $\left(C_{\mathrm{Fe}^{2+}}\right)$, 


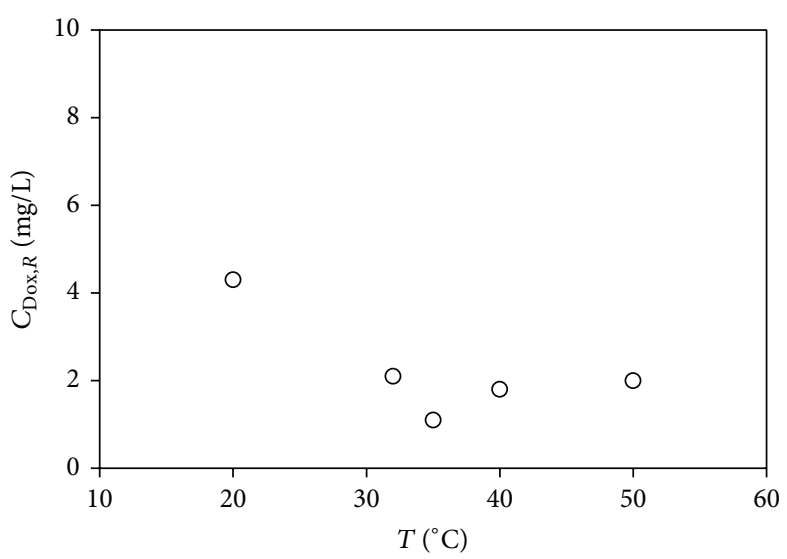

(a)

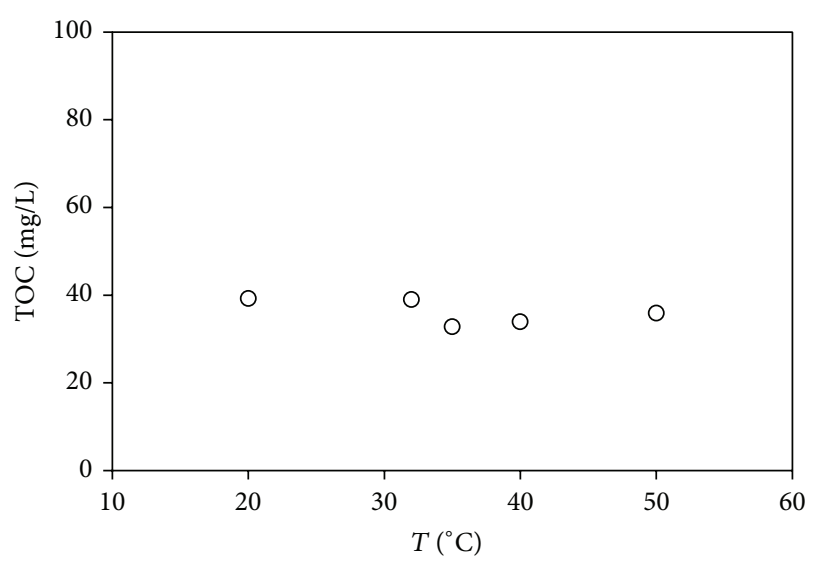

(b)

FIGURE 2: Influence of temperature $(T)$ on residual concentrations of (a) doxycycline $\left(C_{\text {Dox }, R}\right)$ and (b) total organic carbon (TOC) at the end of the Fenton process.

concentration of hydrogen peroxide $\left(\mathrm{C}_{\mathrm{H}_{2} \mathrm{O}_{2}}\right)$, and temperature $(T)$ were selected as the independent variables, while the residual concentrations of doxycycline $\left(C_{\text {Dox, }}\right)$ and total organic carbon (TOC) were the responses. Although one can see a large variation in the residual doxycycline concentration $\left(0 \leq C_{\text {Dox }, R} \leq 55.8 \mathrm{mg} / \mathrm{L}\right)$, incidentally the lowest values $\left(0 \leq C_{\text {Dox }, R} \leq 2 \mathrm{mg} / \mathrm{L}\right)$ were obtained just at the central point $\left(C_{\mathrm{H}_{2} \mathrm{O}_{2}}=500 \mathrm{mg} / \mathrm{L}, C_{\mathrm{Fe}^{2+}}=62.5 \mathrm{mg} / \mathrm{L}\right.$, and $\left.T=20.0^{\circ} \mathrm{C}\right)$, suggesting significant influence of the operating conditions on such a response.

To investigate these effects in greater detail, the experimental results of both responses were worked out using the Statistica software, version 12 (StatSoft, Tulsa, OK, USA), which showed that only $C_{\mathrm{H}_{2} \mathrm{O}_{2}}$ had a statistically significant effect $(P<0.05)$ on $C_{\text {Dox }, R}$, while TOC reduction at the end of tests did not exceed $30 \%$ and was not significantly influenced by any of the independent variables. The best operating conditions to minimize $C_{\mathrm{Dox}, \mathrm{R}}\left(C_{\mathrm{Fe}^{2+}}=25 \mathrm{mg} / \mathrm{L}\right.$, $C_{\mathrm{H}_{2} \mathrm{O}_{2}}=611 \mathrm{mg} / \mathrm{L}$, and $T=35.0^{\circ} \mathrm{C}$ ) were then identified by equating to zero the partial derivatives of the softwaregenerated surface equation

$$
\begin{aligned}
C_{\text {Dox }, R}= & 0.625-3.995 X_{1}+0.015 X_{1}^{2}-7.536 X_{2} \\
& +9.341 X_{2}^{2}-4.540 X_{3}+2.875 X_{3}^{2} \\
& +1.844 X_{1} X_{2}+2.676 X_{1} X_{3}+0.783 X_{2} X_{3}
\end{aligned}
$$

using the coded values of the three independent variables, namely, $C_{\mathrm{Fe}^{2+}}\left(X_{1}\right), C_{\mathrm{H}_{2} \mathrm{O}_{2}}\left(X_{2}\right)$, and $T\left(X_{3}\right)$, that is, finding the function minimum [17]. Such operational conditions were then assumed as the starting point to perform a parametric study, whose results are shown in Figures 2-4 for both responses.

The obtained results allowed estimating for $C_{\text {Dox, } R}$ the regression coefficients listed in Table 2, while those of the related analysis of variance (ANOVA) are presented in Table 3.

Only the linear and quadratic regression coefficients for $X_{2}$ were statistically significant $(P<0.05)$, which means that only the initial concentration of $\mathrm{H}_{2} \mathrm{O}_{2}$ exerted a significant influence on the residual doxycycline concentration in samples collected at the end of the Fenton process.

The experimental results shown in Figures 2-4 confirm those of ANOVA. In particular, temperature did not statistically significantly influence the performance of the Fenton process in terms either of $C_{\mathrm{Dox}, R}$ or of TOC (Figure 2). It is likely that doxycycline was completely degraded into compounds able to react with molybdate in the same way as the antibiotic, thus interfering with the spectrophotometric analysis.

Instead, $C_{\text {Dox, } R}$ was strongly influenced by $C_{\mathrm{H}_{2} \mathrm{O}_{2}}$ (Figure 3(a)), thereby suggesting that low values of this variable did not lead to the formation of hydroxyl radicals in concentration enough to degrade either doxycycline or its degradation products. On the other hand, as expected, the residual concentration of TOC (Figure 3(b)) was found to be independent of $\mathrm{C}_{\mathrm{H}_{2} \mathrm{O}_{2}}$, owing to the sensitivity of the analytical methodology to any organic compound finally present in the medium, that is, not only to doxycycline but also to its oxidation products. Finally, the initial concentration of $\mathrm{Fe}^{2+}$ had a dual effect on $C_{\text {Dox, } R}$, in that for $C_{\mathrm{Fe}^{2+}}<20 \mathrm{mg} / \mathrm{L}$ an increase in this variable led to a remarkable decrease in $C_{\text {Dox }, R}$, while no significant influence was detected beyond this threshold value (Figure 4(a)). Since the same behavior was also observed for TOC (Figure 4(b)), it is likely that, at low $C_{\mathrm{Fe}^{2+}}$ values, the formation of hydroxyl radicals, as in the first case, was insufficient to promote the degradation of both the antibiotic and its oxidation products.

Because of TOC insensitivity to the selected independent variables, to shed light on the phenomena responsible for doxycycline degradation by the Fenton process, samples collected at different times during the test carried out under the best operating conditions $\left(\mathrm{C}_{\mathrm{Fe}^{2+}}=25 \mathrm{mg} / \mathrm{L}, C_{\mathrm{H}_{2} \mathrm{O}_{2}}=\right.$ $611 \mathrm{mg} / \mathrm{L}$, and $T=35.0^{\circ} \mathrm{C}$ ) were analyzed by LCMSIT-TOF, whose mean results in terms of molar masses of doxycycline degradation products are summarized in Table 4, while Figure 5 illustrates the most significant chromatograms. 
TABLE 2: Results of linear (L) and quadratic $(\mathrm{Q})$ regression analyses applied to residual doxycycline concentration data collected at the end of the Fenton process under different operating conditions.

\begin{tabular}{lcccccc}
\hline & Regression coefficient & Standard error & $t$ & $P$ value & 95\% Lower confidence limit & 95\% Upper confidence limit \\
\hline Mean & 0.625 & 3.688 & 0.169 & 0.868 & -7.59 & 8.85 \\
$X_{1}(\mathrm{~L})$ & -3.995 & 2.448 & -1.635 & 0.132 & -9.46 & 1.45 \\
$X_{1}(\mathrm{Q})$ & -0.015 & 2.386 & -0.005 & 0.995 & -5.33 & 5.30 \\
$X_{2}(\mathrm{~L})$ & -7.536 & 2.448 & -3.078 & 0.011 & -12.99 & -2.08 \\
$X_{2}(\mathrm{Q})$ & 9.341 & 2.386 & 3.914 & 0.002 & 4.02 & 14.66 \\
$X_{3}(\mathrm{~L})$ & -4.540 & 2.448 & -1.849 & 0.094 & -9.98 & 0.93 \\
$X_{3}(\mathrm{Q})$ & 2.875 & 2.386 & 1.204 & 0.256 & -2.44 & 8.19 \\
$X_{1} X_{2}$ & 1.844 & 3.198 & 0.578 & 0.575 & -5.28 & 8.98 \\
$X_{1} X_{3}$ & 2.676 & 3.198 & 0.828 & 0.426 & -4.48 & 9.78 \\
$X_{2} X_{3}$ & 0.783 & 3.198 & 0.242 & 0.813 & -6.35 & 7.90 \\
\hline
\end{tabular}

$\mathrm{L}=$ linear regression; $\mathrm{Q}=$ quadratic regression; $t=$ Student's $t$-test; $X_{1}=$ codified values of $C_{\mathrm{Fe}^{2+}} ; X_{2}=$ codified values of $C_{\mathrm{H}_{2} \mathrm{O}_{2}} ; X_{3}=$ codified values of $T$.

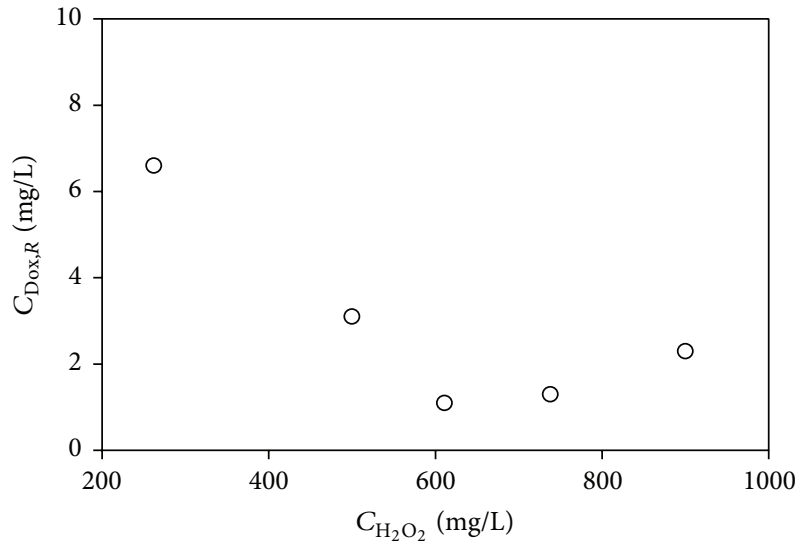

(a)

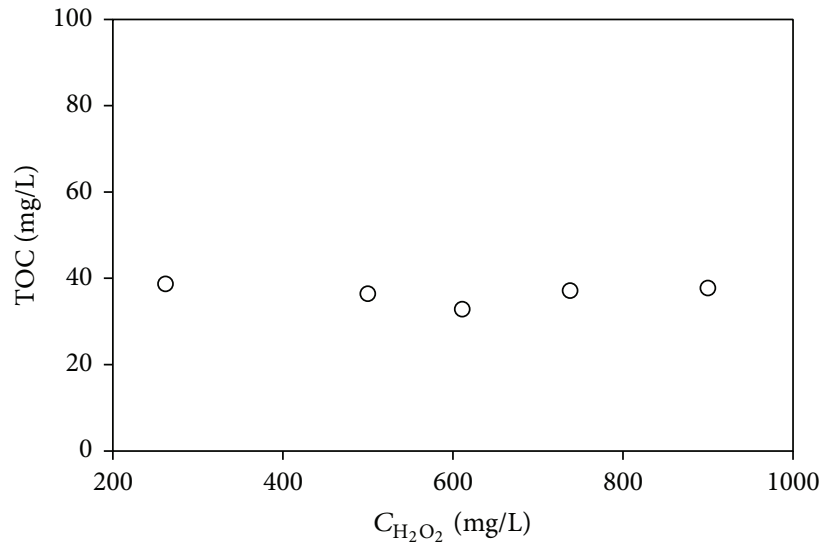

(b)

FIGURE 3: Influence of initial hydrogen peroxide concentration $\left(C_{\mathrm{H}_{2} \mathrm{O}_{2}}\right)$ on residual concentrations of (a) doxycycline $\left(C_{\text {Dox,R }}\right)$ and (b) total organic carbon (TOC) at the end of the Fenton process.

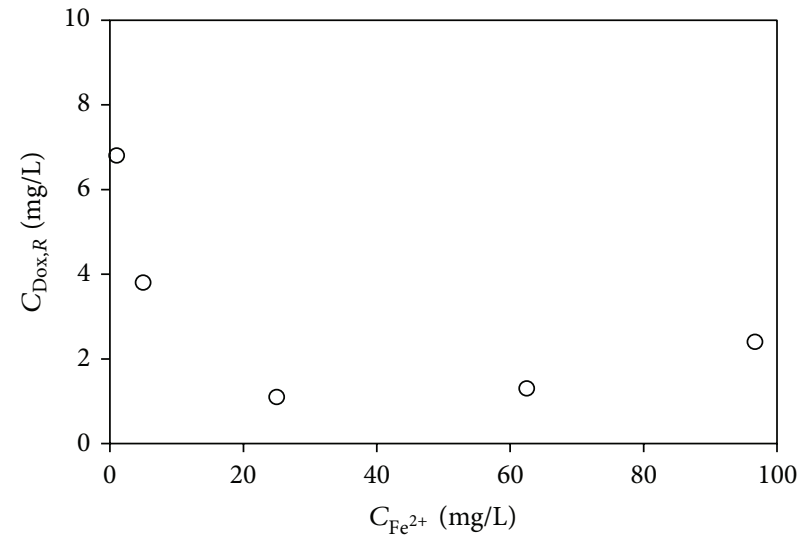

(a)

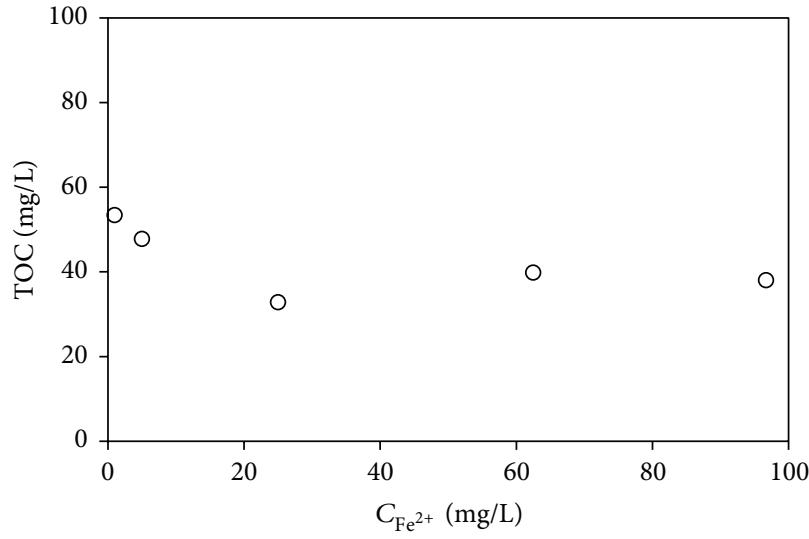

(b)

FIGURE 4: Influence of initial concentration of ferrous ion $\left(C_{\mathrm{Fe}^{2+}}\right)$ on final concentrations of (a) doxycycline $\left(C_{\mathrm{Dox}, R}\right)$ and (b) total organic carbon (TOC) at the end of the Fenton process. 
TABLE 3: (a) Results of the analysis of variance applied to residual doxycycline concentration data collected at the end of the Fenton process under different operating conditions. (b) Results obtained by the quadratic model.

(a)

\begin{tabular}{lccccc}
\hline & Sum of squares & Degrees of freedom & Mean square & $F$-calc. & $P$ value \\
\hline$X_{1}(\mathrm{~L})$ & 218.87 & 1 & 218.868 & 2.68 & 0.133 \\
$X_{1}(\mathrm{Q})$ & 0.003 & 1 & 0.002 & 0.00 & 0.998 \\
$X_{2}(\mathrm{~L})$ & 775.21 & 1 & 775.219 & 9.50 & 0.012 \\
$X_{2}(\mathrm{Q})$ & 1253.19 & 1 & 1253.195 & 15.36 & 0.003 \\
$X_{3}(\mathrm{~L})$ & 279.76 & 1 & 279.760 & 3.43 & 0.094 \\
$X_{3}(\mathrm{Q})$ & 118.65 & 1 & 118.652 & 1.46 & 0.255 \\
$X_{1} X_{2}$ & 27.38 & 1 & 27.380 & 0.33 & 0.575 \\
$X_{1} X_{3}$ & 56.18 & 1 & 56.180 & 0.69 & 0.426 \\
$X_{2} X_{3}$ & 4.805 & 1 & 4.805 & 0.06 & 0.813 \\
\hline
\end{tabular}

(b)

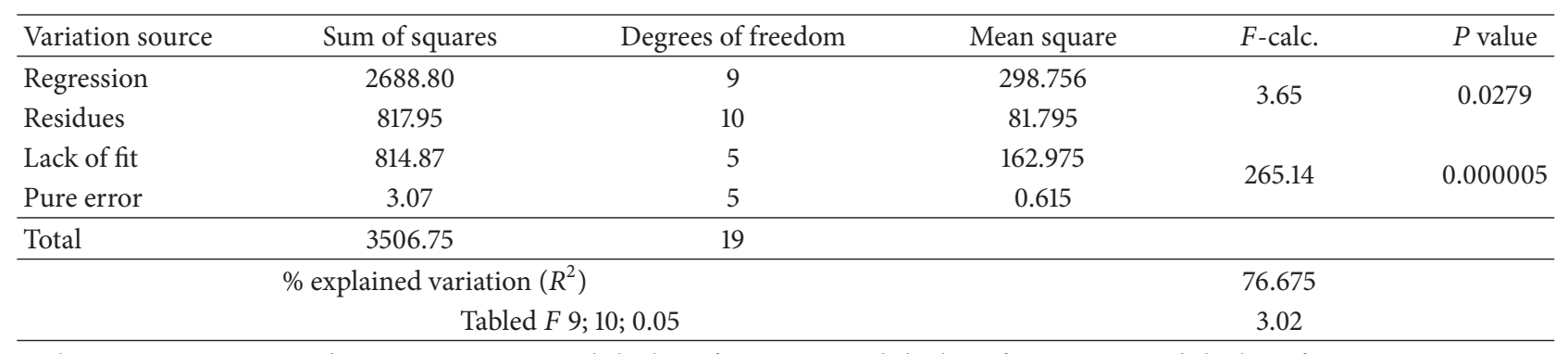

$\mathrm{L}=$ linear regression; $\mathrm{Q}=$ quadratic regression; $X_{1}=$ coded values of $C_{\mathrm{Fe}^{2+}} ; X_{2}=$ coded values of $C_{\mathrm{H}_{2} \mathrm{O}_{2}} ; X_{3}=$ coded values of $T$.

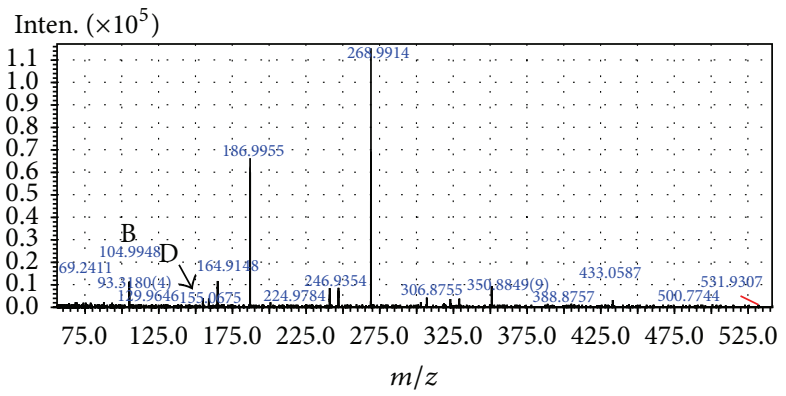

(a)

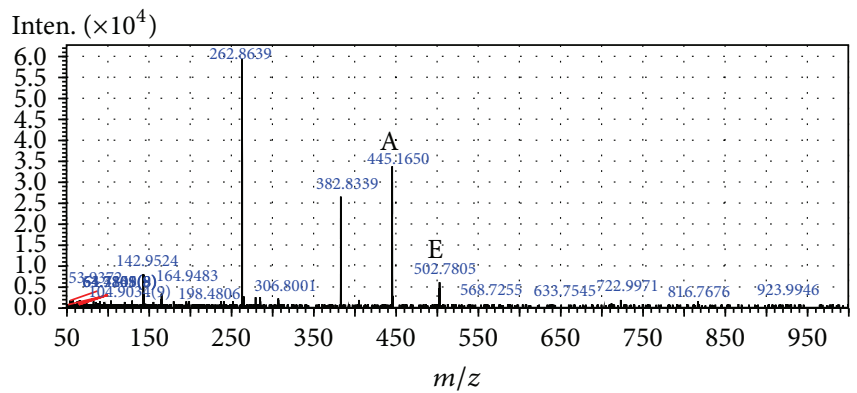

(b)

FIGURE 5: LCMS-IT-TOF results of doxycycline samples submitted to the Fenton process (a) for $60 \mathrm{~s}$, retention time of $41 \mathrm{~s}$, (b) for $180 \mathrm{~s}$, retention time of $54 \mathrm{~s}$. Operating conditions of the Fenton process: $C_{\mathrm{Fe}^{2+}}=25 \mathrm{mg} / \mathrm{L}, C_{\mathrm{H}_{2} \mathrm{O}_{2}}=611 \mathrm{mg} / \mathrm{L}$, and $T=35.0^{\circ} \mathrm{C}$. A, B, D, and E: doxycycline degradation products with $\mathrm{MM}=444,104,154$, and $502 \mathrm{~g} / \mathrm{mol}$, respectively.

Based on these results, it is evident that doxycycline, which has an empirical formula of $\mathrm{C}_{22} \mathrm{H}_{24} \mathrm{~N}_{2} \mathrm{O}_{8}$ and a molar mass (MM) of $444 \mathrm{~g} / \mathrm{mol}$ (Figure 6, A), was completely degraded by the Fenton process within only $10 \mathrm{~min}$, that is, already at the beginning of the process, mainly leading to products with less MM (104-399 $\mathrm{g} / \mathrm{mol})$ and even one with higher MM (502 g/mol) (E) (Table 4). One can believe that initially formed degradation products suffered an attack by the hydroxyl radical that caused the formation of unstable compounds able to react with other molecules present in the medium, hence allowing the formation of more stable compounds, while maintaining a high TOC level. These results suggest that the hydroxyl radical was capable of promoting either the loss of atoms and functional groups located at doxycycline molecules periphery or the breakdown of aromatic rings.

According to these results, we sought to identify the main degradation products by comparison with structures proposed by other authors $[9,11,13]$ (Figure 6, B-D). In particular, Yuan et al. [11], who investigated the products of doxycycline photolysis by $\mathrm{UV}$ and $\mathrm{UV} / \mathrm{H}_{2} \mathrm{O}_{2}$, identified the same $\mathrm{MM}=104 \mathrm{~g} / \mathrm{mol}$ compound detected in this work as propanedioic acid (Figure 6, B), which was the likely result of the breakdown of rings of the drug molecule. The same 
<smiles>C[C@H]1c2cccc(O)c2C(=O)C2=C(O)[C@]3(O)C(=O)C(C(N)=O)=C(O)C(N(C)C)C3C(O)C21</smiles>

A (444)<smiles>O=C(O)CC(=O)O</smiles>

B (104)

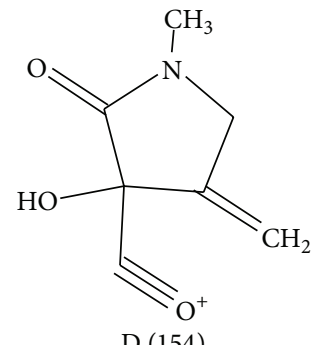<smiles>CC1c2cc(O)cc(O)c2C(=O)C2=C(O)[C@]3(O)C(=O)C4=C(OC4(O)CC(=O)O)C(N(C)C)C3C(O)C21</smiles>

$\mathrm{D}(502)$<smiles>C[C@H]1C2=C(C(=O)c3c(O)cccc31)C(O)C1C(N(C)C)C(O)=CC(=O)[C@]1(O)C2O</smiles><smiles>CC(=CN(C)C)C(C#[O+])=CO</smiles>

$\mathrm{D}(154)$

Figure 6: Molecular structures of doxycycline (A) and its degradation products with molar mass of $104 \mathrm{~g} / \mathrm{mol}$ (B), $399 \mathrm{~g} / \mathrm{mol}(\mathrm{C})$, and $154 \mathrm{~g} / \mathrm{mol}(\mathrm{D})[9,11,13]$. (E) Molecular structure of doxycycline degradation product with molar mass of $502 \mathrm{~g} / \mathrm{mol}$.

authors also found a product with $\mathrm{MM}=186 \mathrm{~g} / \mathrm{mol}$, like that detected in our work, but did not suggest any molecular structure for it.

Jeong et al. [9], who analyzed doxycycline degradation products formed by the action of hydroxyl radicals generated by the electron pulse radiolysis of water, reported the presence, among others, of a compound with $\mathrm{MM}=$ $399 \mathrm{~g} / \mathrm{mol}$ and suggested for it the molecular structure shown in Figure 6, C. On the other hand, Maroga Mboula et al. [13], using the heterogeneous photocatalysis with $\mathrm{TiO}_{2}$, identified, among the degradation products of tetracycline, which differs from doxycycline only for the presence of an additional $\mathrm{OH}$, a compound with $\mathrm{MM}=154 \mathrm{~g} / \mathrm{mol}$, for which they suggested two possible molecular structures (Figure 6, D). Finally, based on the results of search in the database of ChemSpider (Royal Society of Chemistry, Cambridge, UK), we are able to propose for the product with the highest MM $(502 \mathrm{~g} / \mathrm{mol})$, detected in samples withdrawn from the medium after 3, 5, and $10 \mathrm{~min}$, the structure E illustrated in Figure 6, which could be explained by (a) replacement of the amino group with a carboxymethyl group, (b) attack of a hydroxyl group to the $\alpha$ ring, and (c) formation of a cycle adjacent to the $\delta$ ring of doxycycline.

\section{Conclusions}

In this work, dealing with doxycycline degradation by the Fenton process, the optimal conditions of initial concentrations of ferrous ion $\left(\mathrm{C}_{\mathrm{Fe}^{2+}}\right)$ and hydrogen peroxide $\left(\mathrm{C}_{\mathrm{H}_{2} \mathrm{O}_{2}}\right)$ and of temperature $(T)$, able to minimize the residual doxycycline $\left(C_{\mathrm{Dox}, R}\right)$ and total organic carbon (TOC) concentrations, were identified through a Rotational Central Composite Design.

A parametric analysis highlighted that the above three variables exerted different effects on $C_{\text {Dox }, R}$, but the analysis of variance showed that $\mathrm{C}_{\mathrm{H}_{2} \mathrm{O}_{2}}$ was the only one that statistically significantly influenced it. The best experimental conditions able to minimize both residual doxycycline $(1.1 \mathrm{mg} / \mathrm{L})$ and TOC $(32.8 \mathrm{mg} / \mathrm{L})$ concentrations were $C_{\mathrm{Fe}^{2+}}=25 \mathrm{mg} / \mathrm{L}$, $C_{\mathrm{H}_{2} \mathrm{O}_{2}}=611 \mathrm{mg} / \mathrm{L}$, and $T=35.0^{\circ} \mathrm{C}$. The TOC results showed that the organic load was not significantly reduced, which indicates that the Fenton process led to the formation of doxycycline oxidation products sensitive to the TOC analytical methodology.

A LCMS-IT-TOF investigation allowed identifying the main degradation products of doxycycline oxidation, which were mainly constituted by low molar mass products 
TABLE 4: Molar masses of the main doxycycline degradation products identified by LCMS-IT-TOF at different sampling times during tests carried out under the best operating conditions identified by the RCCD $\left(C_{\mathrm{Fe}^{2+}}=25 \mathrm{mg} / \mathrm{L}, C_{\mathrm{H}_{2} \mathrm{O}_{2}}=611 \mathrm{mg} / \mathrm{L}\right.$, and $\left.T=35.0^{\circ} \mathrm{C}\right)$. (A) Doxycycline, (B-E) main doxycycline degradation products.

\begin{tabular}{|c|c|c|c|c|c|}
\hline \multirow{3}{*}{ Retention time (s) } & \multicolumn{5}{|c|}{ Sampling time (s) } \\
\hline & 30 & 60 & 180 & 300 & 600 \\
\hline & \multicolumn{5}{|c|}{ Molar mass (g/mol) } \\
\hline \multirow{8}{*}{41} & $104(\mathrm{~B})$ & $104(\mathrm{~B})$ & $104(\mathrm{~B})$ & $104(\mathrm{~B})$ & 115 \\
\hline & 164 & $154(\mathrm{D})$ & 164 & 186 & 186 \\
\hline & 186 & 164 & 186 & 240 & 240 \\
\hline & 240 & 184 & 240 & 268 & 268 \\
\hline & 269 & 244 & 268 & 306 & 350 \\
\hline & 350 & 268 & 350 & 350 & - \\
\hline & - & 306 & - & 382 & - \\
\hline & - & 350 & - & 432 & - \\
\hline \multirow{7}{*}{54} & 142 & 142 & 142 & 142 & 142 \\
\hline & 164 & 164 & 262 & 262 & 164 \\
\hline & 262 & 262 & 382 & 306 & 262 \\
\hline & 382 & 306 & $444(\mathrm{~A})$ & 382 & 306 \\
\hline & $444(\mathrm{~A})$ & 382 & $502(\mathrm{E})$ & $444(\mathrm{~A})$ & 382 \\
\hline & - & $444(\mathrm{~A})$ & - & $502(\mathrm{E})$ & 404 \\
\hline & - & - & - & - & $502(\mathrm{E})$ \\
\hline \multirow{4}{*}{72} & - & 74 & - & - & - \\
\hline & - & 262 & - & - & - \\
\hline & - & 339 & - & - & - \\
\hline & - & $399(\mathrm{C})$ & - & - & - \\
\hline
\end{tabular}

$(104-399 \mathrm{~g} / \mathrm{mol})$ as well as a product with higher molar mass $(502 \mathrm{~g} / \mathrm{mol})$ than doxycycline.

\section{Conflict of Interests}

The authors declare that there is no conflict of interests regarding the publication of this paper.

\section{Acknowledgment}

The authors are grateful to Professor Claudio Augusto Oller do Nascimento, Coordinator of the Laboratory of Process Simulation and Control (LSCP) and of the Center of Chemical System Engineering (CESQ) of the Department of Chemical Engineering of Polytechnic School of the University of São Paulo for the use of TOC and LCMS-IT-TOF equipment.

\section{References}

[1] D. S. Aga, Fate of Pharmaceuticals in the Environment and in Water Treatment Systems, CRC Press, Boca Raton, Fla, USA, 2008.

[2] S. J. Khan and J. E. Ongerth, "Modelling of pharmaceutical residues in Australian sewage by quantities of use and fugacity calculations," Chemosphere, vol. 54, no. 3, pp. 355-367, 2004.

[3] A. J. Watkinson, E. J. Murby, D. W. Kolpin, and S. D. Costanzo, "The occurrence of antibiotics in an urban watershed: from wastewater to drinking water," Science of the Total Environment, vol. 407, no. 8, pp. 2711-2723, 2009.
[4] J. Rivas, Á. Encinas, F. Beltrán, and N. Graham, “Application of advanced oxidation processes to doxycycline and norfloxacin removal from water," Journal of Environmental Science and Health, Part A-Toxic/Hazardous Substances and Environmental Engineering, vol. 46, no. 9, pp. 944-951, 2011.

[5] D. P. Rocha, G. F. Pinto, R. Ruggiero et al., "Coordination of metals to antibiotics as a strategy to combat bacterial resistance," Química Nova, vol. 34, no. 1, pp. 111-118, 2011.

[6] C. Gu and K. G. Karthikeyan, "Interaction of tetracycline with aluminum and iron hydrous oxides," Environmental Science and Technology, vol. 39, no. 8, pp. 2660-2667, 2005.

[7] E. C. Pereira-Maia, P. P. Silva, W. B. De Almeida et al., "Tetracyclines and glycylcyclines: an overview," Quimica Nova, vol. 33, no. 3, pp. 700-706, 2010.

[8] A. A. Borghi and M. S. A. Palma, "Tetracycline: production, waste treatment and environmental impact assessment," Brazilian Journal of Pharmaceutical Sciences, vol. 50, no. 1, pp. 1-16, 2014.

[9] J. Jeong, W. Song, W. J. Cooper, J. Jung, and J. Greaves, “Degradation of tetracycline antibiotics: mechanisms and kinetic studies for advanced oxidation/reduction processes," Chemosphere, vol. 78, no. 5, pp. 533-540, 2010.

[10] G. G. Zhanel, K. Homenuik, K. Nichol et al., "The glycylcyclines: a comparative review with the tetracyclines," Drugs, vol. 64, no. 1, pp. 63-88, 2004.

[11] F. Yuan, C. Hu, X. Hu, D. Wei, Y. Chen, and J. Qu, "Photodegradation and toxicity changes of antibiotics in UV and $\mathrm{UV} / \mathrm{H}_{2} \mathrm{O}_{2}$ process," Journal of Hazardous Materials, vol. 185, no. 2-3, pp. 1256-1263, 2011. 
[12] S. M. Sunaric, S. S. Mitic, G. Z. Miletic, A. N. Pavlovic, and D. Naskovic-Djokic, "Determination of doxycycline in pharmaceutical based on its degradation by $\mathrm{Cu}(\mathrm{II}) / \mathrm{H}_{2} \mathrm{O}_{2}$ reagent in aqueous solution," Journal of Analytical Chemistry, vol. 64, no. 3, pp. 231-237, 2009.

[13] V. Maroga Mboula, V. Héquet, Y. Gru, R. Colin, and Y. Andrès, "Assessment of the efficiency of photocatalysis on tetracycline biodegradation," Journal of Hazardous Materials, vol. 209-210, pp. 355-364, 2012.

[14] B. Barros Neto, I. S. Scarminio, and R. E. Bruns, Como Fazer Experimentos, Pesquisa e Desevolvimento na Ciência e na Indústria, UNICAMP, Campinas, Brazil, 2nd edition, 2002.

[15] M. I. Rodrigues and A. F. Iemma, Planejamento de Experimentos e Otimização de Processos: uma Estratégia Sequencial de Planejamentos, Casa do Pão Editora, Campinas, Brazil, 2005.

[16] A. L. N. Mota, C. T. Muranaka, J. E. F. Moraes, C. A. O. Nascimento, and O. Chiavone-Filho, "Aplicação do processo Foto-Fenton na fotodegradação do fenol em meio aquoso utilizando lâmpadas de luz negra como fonte de radiação," in $21 s t$ Congreso Interamericano de Ingeniería Química, Lima, Peru, April 2005.

[17] P. K. Pandey, H. S. Ramaswamy, and D. Gelais, "Water-holding capacity and gel strength of rennet curd as affected by highpressure treatment of milk," Food Research International, vol. 33, no. 8 , pp. 655-663, 2000. 

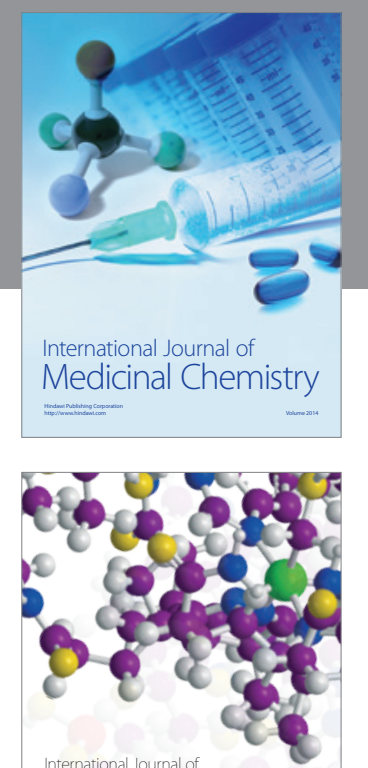

\section{Carbohydrate} Chemistry

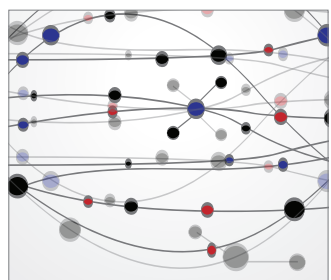

The Scientific World Journal
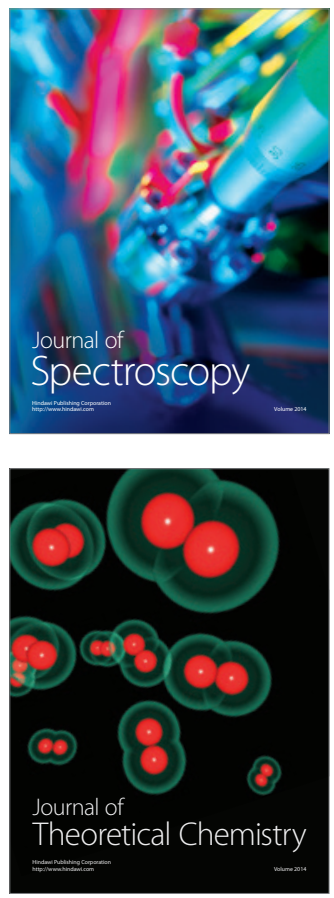
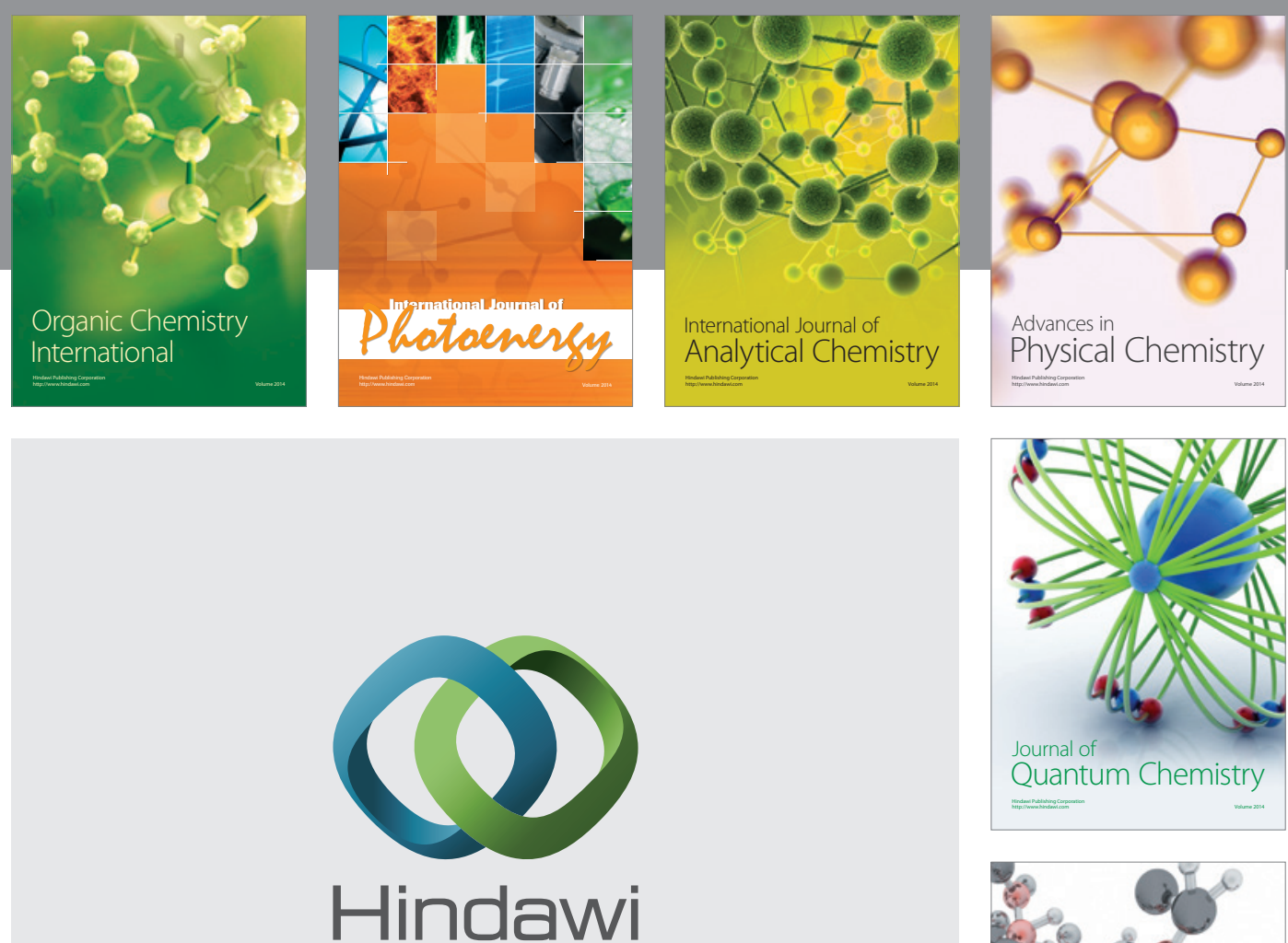

Submit your manuscripts at

http://www.hindawi.com

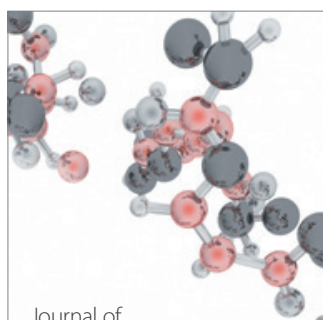

Analytical Methods

in Chemistry

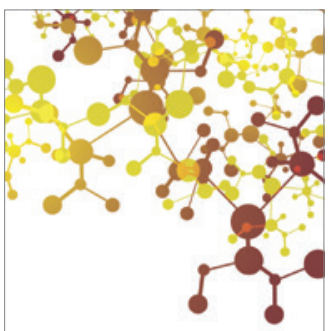

Journal of

Applied Chemistry

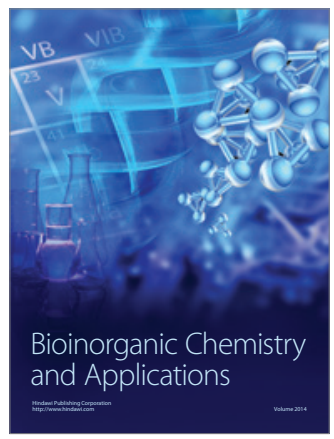

Inorganic Chemistry
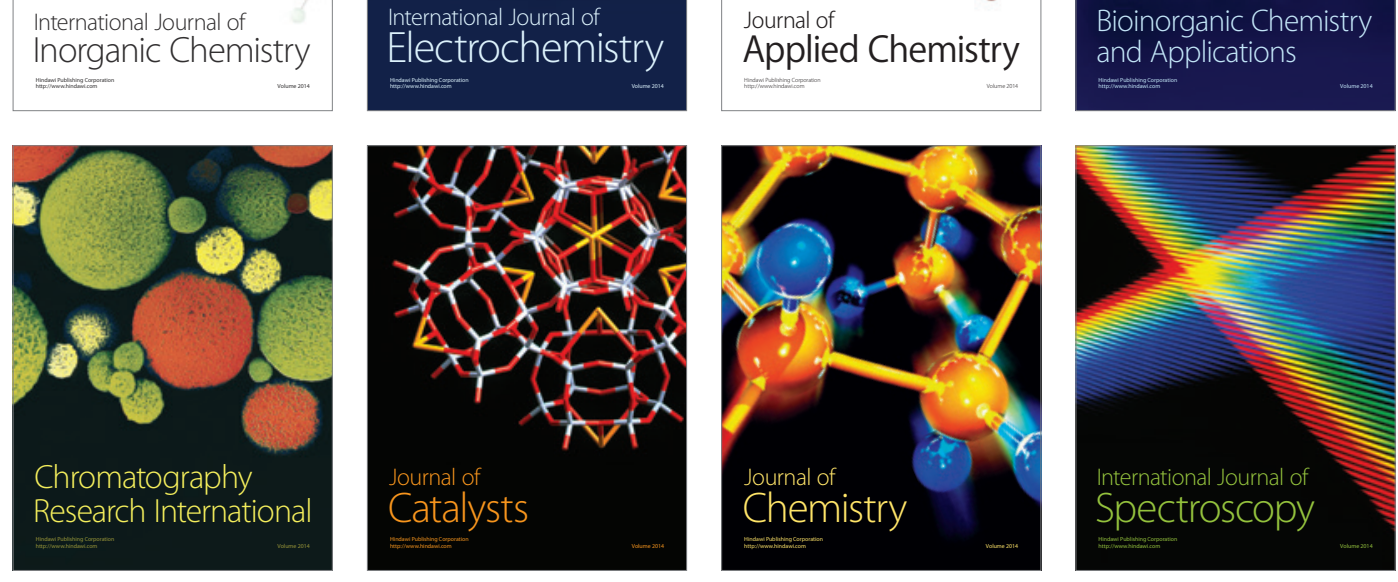